\title{
ANALISA TINGKAT KEPATUHAN PENGGUNAAN TERAPI OBAT ORAL ANTIDIABETIK (OAD) PADA PASIEN DIABETES MELLITUS DI INSTALASI RSUD. A.W SJAHRANIE
}

\author{
Rina Fitriani, Muhammad Amir Masruhim, Dewi Rahmawati \\ Instalasi Rawat Jalan RSUD. A. W. Sjahranie “APOTEK RAWAT JALAN” Fakultas \\ Farmasi Universitas Mulawarman, Samarinda, Kalimantan Timur \\ email: rinafitriani1193@gmail.com
}

\begin{abstract}
Patient compliance in taking medication drug an important role in the success of long-term treatment of chronic and degenerative disease, for example Diabetes Mellitus (DM). There are two pharmacological therapies of Diabetes Mellitus, injection insulin and oral medications. Oral antidiabetic drugs (AOD) should be consumed every day and continuously, therefore may affects the level of patients compliance. Good knowledge, confidence for recovery, and family support are several things that can increase the patient compliance ini taking the medication. The aim of this research characteristics of DM patient and is to study the compliance level of DM patient in taking OAD. This research is a descriptive study with cross sectional method on 60 patients DM by distributing questionnaires in hospitals AW Sjahranie. The sampling technique is random sampling. The results showed $73.3 \%$ patients have high compliance. The results obtained in patients who are mostly women, aged 36-60 years old, high school education, and housewives.
\end{abstract}

Keyword: Compliance, Diabetes Mellitus, OAD

\begin{abstract}
ABSTRAK
Kepatuhan pasien dalam mengkonsumsi obat berperan penting dalam keberhasilan pengobatan jangka panjang prnyakit kronis dan degeneratif, salah satunya Diabetes Mellitus (DM). Terapi farmakologi Diabetes Mellitus terdiri dari 2 yaitu injeksi insulin dan obat oral. Obat Oral Antidiabetik (AOD) yang harus minum setiap hari akan berdampak pada kepatuhan pasien. Pengetahuan yang baik, keyakinan akan sembuh dan dukungan dari keluarga adalah beberapa hal yang dapat meningkatkan kepatuhan pasien dalam mengkonsumsi obat. Penelitian ini bertujuan untuk mengetahui karakteristik pasien DM dan mengetahui kepatuhan pasien DM dalam mengkonsumsi OAD. penelitian ini adalah penelitian deskriptif dengan metode Cross Sectional terhadap 60 pasien DM dengan membagikan kuesioner di RSUD A.W Sjahranie. Teknik pengambilan sampel adalah random sampling. Hasil penelitian menunjukkan $73,3 \%$ pasien memiliki tingkat kepatuhan yang tinggi. Hasil tersebut didapat pada pasien yang sebagian besar adalah perempuan, usia 36-60 tahun, pendidikan SMA, dan ibu rumah tangga.
\end{abstract}

Kunci: Kepatuhan, Diabetes Mellitus, OAD

\section{PENDAHULUAN}

Diabetes mellitus (DM) adalah kelainan metabolik yang memeiliki hiperglikemia kronik dengan gangguan metabolism karbohidrat, lemak, dan protein akibat terjadinya defek pada sekresi insulin, aksi insulin, atau keduanya. Jumlah penderita Diabetes Mellitus 
pada tahun 200 di Indonesia menempati urutan ke-4 terbesar dalam jumlah penderita Diabetes Mellitus dengan prevalensi 8,4 juta jiwa. Urutan diatasnya adalah India (31,7 juta jiwa), Cina (20,8 juta jiwa). Dan Amerika Serikat (17,7 juta jiwa)(Darmono, 2007). Pada tahun 2010 jumlah penderita Diabetes Mellitus di Indonesia minimal menjadi 5 juta dan di dunia 239,9 juta penderita. Diperkirakan pada tahun 2030 prevalensi Diabetes Mellitus di Indonesia meningkat menjadi 21,3 juta. Angka kesakitan dan kematian akibat Diabetes Mellitus di Indonesia cenderung meningkat setiap tahunnya sejalan dengan perubahan gaya hidup masyarakat yang mengarah pada makanan siap saji dan makanan yang kaya akan kandungan karbohidrat.

Kalimantan Timur, penyakit Diabetes Mellitus telah menduduki urutan ke-5 dari 10 penyakit terbanyak di provinsi Kalimantan Timur. Prevalensi Diabetes Mellitus di Kalimantan Timur adalah sebesar 1,3\% dengan prevalensi tertinggi di Bulungan 1,7\% dan Samarinda $1,6 \%$. Melihat dari karakteristik penderita bahwa prevalensi terbesar pada usia $>65$ tahun 10,8\%. Meningkatnya penderita penyakit Diabetes Mellitus diantaranya disebabkan karena faktor genetik dan gaya hidup modern, seperti sering mengkonsumsi makanan berlemak, kurang istirahat, jarang melakukan aktivitas olahraga, stress yang tinggi dan tidak patuh terhadap terapi obat terutama obat oral yang diberikan yang dapat meningkatkan resiko tinggi Diabetes Mellitus. Resiko tinggi yang dimaksud seperti hipertensi, gagal ginjal bahkan kematian. Hal ini dikarenakan adanya faktor ketidakpatuhan pasien terhadap terapi yang telah diberikan. Misalnya dari penyakit yang diderita pasien, sehingga kebanyakan pasien putus asa dengan terapi yang begitu lama dan tidak menghasilkan kesembuhan. Selain itu dari regimen terapi obat meliputi terapi multi obat, yang menunjukkan semakin banyak jumlah obat maka semakin tinggi resiko ketidakpatuhan. Frekuensi pemberian, membuat pasien sering lupa akan pemberian obat dalam jangka waktu yang sering. Durasi dan terapi, pasien merasa bosan akan pengobatan yang begitu lama. Efek yang merugikan dari banyaknya obat yang dikonsumsi sehingga cukup menyusahkan pasien. Harga obat yang terlalu mahal sehingga membuat pasien tidak dapat menebus obat. Dan rasa obat yang pahit terutama cairan oral yang membuat pasien malas untuk minum obat. Sehingga dari semua faktor ketidakpatuhan diatas akan mengakibatkan penggunaan suatu obat yang kurang atau lebih.

\section{METODE PENELITIAN}

Penelitian ini dilakukan di Instalasi Rawat Jalan RSUD.A.W Sjahranie Samarinda pada bulan Agustus 2015. Sampel adalah seluruh penderita Diabates Mellitus dengan penyakit komplikasi dan tanpa komplikasi. Teknik pengambilan sampel adalah dengan menggunakan teknik random sampling. Penelitian ini dilakukan secara deskriptif dengan metode Cross Sectional terhadap 60 pasien DM dengan membagikan kuesioner. Validasi kuesioner dilakukan di Puskesmas Segiri, sedangkan penelitian dilakukan di RSUD.A.W Sjahranie. Pengolahan data diperoleh berupa data persentase dan disajikan ke dalam bentuk tabel atau diagram.

\section{HASIL DAN PEMBAHASAN}

\section{Karakteristik responden}

Analisis ini bertujuan untuk mengetahui karakteristik responden (umur, jenis kelamin). Berdasarkan lembar observasi yang telah diisi responden didapatkan hasil yaitu didapatkan data bahwa dari 60 responden, sebagian besar responden berusia 36-60 tahun yaitu sebanyak 55 pasien $(91,7 \%)$, sementara responden berusia <20 tahun sebanyak 3 pasien (5,0\%), responden yang berusia 21-35 tahun sebanyak 2 pasien $(3,3 \%)$ dan responden yang berusia $>70$ tahun sebanyak 0 pasien $(0 \%)$. 
Tabel 1. Distribusi Pasien Diabetes mellitus Berdasarkan Umur

\begin{tabular}{ccc}
\hline Usia & Frekuensi (f)) & Persentase (\%) \\
\hline$<20$ tahun & 3 & 5,0 \\
$21-35$ tahun & 2 & 3,3 \\
$36-60$ tahun & 55 & 91,7 \\
$>60$ tahun & - & - \\
\hline Total & 60 & 100 \\
\hline
\end{tabular}

Hasil penelitian menujukkan bahwa usia pasien cenderung lebih tua, dimana pada penelitian terlihat usia pasien yang menjadi subjek rata-rata berkisar 40-60 tahun. Hasil penelitian pada tabel 5.2 ini telah sesuai dengan teori, dimana diabetes mellitus tipe 2 meningkat seiring dengan bertambahnya usia. Penuaan sangat mempengaruhi banyak hormon untuk mengatur metabolism tubuh, reproduksi dan fungsi tubuh lainnya. Penuaan mempengaruhi sensitivitas sel beta pancreas terhadap glukosa dan menunda pengambilan glukosa yang dimediasi oleh insulin (Wirawan,2014). Selain itu dimana pada usia tersebut wanita sedang mengalami premenopouse. Pada saat premenopause, hormone estrogen menurun yang berdampak pada peningkatan resistensi insulin.

Tabel 2. Distribusi Pasien Diabetes mellitus Berdasarkan Jenis Kelamin

\begin{tabular}{ccc}
\hline Jenis Kelamin & Frekuensi (f)) & Persentase (\%) \\
\hline Laki-laki & 20 & 33,3 \\
Perempuan & 40 & 66,7 \\
\hline Total & 60 & 100 \\
\hline
\end{tabular}

Hasil penelitian pada tabel 2 menunjukkan bahwa jenis kelamin perempuan lebih banyak menderita diabetes mellitus dibandingkan dengan laki-laki. Dibuktikan dengan hasil bahwa pada perempuan sebanyak 40 pasien $(66,7 \%)$, sedangkan laki-laki sebanyak 20 pasien $(33,3 \%)$. Faktor yang dapat menyebabkan dominannya perempuan dari pada laki-laki adalah pada saat pramenopouse dan pasca menopause, dimana kadar estrogen dan progesteron dalam tubuh yang semakin berkurang. Hormon estrogen berperan dalam membantu metabolisme lemak dan mengatur pola distribusi lemak di bawah kulit, sehingga ketika perempuan mengalami monopouse terjadi penumpukan lemak yang beresiko terjadinya gangguan toleransi glukosa. Penumpukan lemak yang terjadi akan mengganggu kemampuan insulin untuk mempengaruhi pengambilan glukosa dan metabolisme yang sensitif terhadap insulin (resistensi insulin). Dimana ketika terjadi penumpukan lemak, di dalam sel hubungan pengikatan insulin dengan reseptor spesifik akan berkurang. Sehingga ketika kadar estrogen dan progesteron menurun, dapat menyebabkan metabolisme glukosa yang buruk, sehingga lebih rentan terkena diabetes mellitus. Sedangkan laki-laki tidak memiliki kedua hormon tersebut, tatapi laki-laki memungkinkan untuk merokok dari pada perempuan yang dapat meningkatkan resiko dari gangguan glukosa dengan mengurangi sensitifitas dari insulin (Reni,2014). Merokok dan diabetes saling terkait, dimana merokok dapat memperparah penyakit gula seseorang. Beberapa kandungan rokok seperti nikotin dapat merusak dinding pembuluh darah yang mengakibatkan adanya tekanan darah tinggi dan stroke. Pengaruh rokok (nikotin) dapat merangsang kelenjar adrenal sehingga dapat meningkatkan kadar glukosa darah. Selain dari faktor merokok, faktor lain adalah pengaruh dari metabolik sindrom. Metabolik 
sindrom adalah sekumpulan penyimpangan fungsi tubuh baik lipid maupun non lipid yang berupa obesitas sentral (kegemukan terutama berdasarkan ukuran lingkar perut yang berlebih), tekanan darah tinggi (pra-hipertensi atau hipertensi), dislipidemia (peningkatan kadar kolesterol terutama LDL, trigliserida dan rendahnya kadar HDL). Salah satu metabolik sindrom adalah obesitas/kegemukan. Dimana obesitas terjadi karena semakin banyak lemak yang menumpuk di dalam tubuh. sehingga tubuh semakin resisten terhadap kerja insulin, terutama apabila lemak tubuh terkumpul didaerah sentral atau perut. Lemak dapat memblokir kerja insulin sehingga glukosa tidak dapat di angkut ke dalam sel dan menumpuk dalam pembuluh darah yang menyebabkan terjadi peningkatan kadar glukosa darah. Sehingga laki-laki maupun perempuan memiliki kesempatan yang sama untuk menderita diabetes tipe2. American Diabetes Association menyatakan bahwa jenis kelamin tertentu bukan merupakan faktor resiko terjadinya diabetes mellitus meliputi obesitas, ras, hipertensi, dyslipidemia, riwayat diabetes mellitus gestasional, serta pernah melahirkan bayi dengan berat lebih dari $4 \mathrm{~kg}$ (Wirawan, 2014).

Tabel 3. Distribusi Pasien Diabetes mellitus Berdasarkan Pendidikan

\begin{tabular}{ccc}
\hline Pendidikan & Frekuensi (f)) & Persentase (\%) \\
\hline SD & 19 & 31,7 \\
SMP & 8 & 13,3 \\
SMA & 21 & 35,0 \\
Perguruan & 12 & 20,0 \\
Tinggi & & \\
\hline Total & 60 & 100 \\
\hline
\end{tabular}

Hasil penelitian menunjukkan bahwa pasien diabetes mellitus terbanyak dengan pendidikan terakhir SMA sebanyak 21 pasien $(35,0 \%)$, sedangkan SMP 8 pasien $(13,3 \%)$ dan SD sebanyak 19 pasien $(31,7 \%)$. Hal ini tidak sesuai dengan teori dimana tingkat pendidikan dapat mempengaruhi kemampuan dan pengetahuan seseorang dalam menerapkan perilaku hidup sehat.. Sehingga semakin tinggi tingkat pendidikan maka semakin tinggi pula kemampuan seseorang dalam menjaga gaya hidup dan semakin banyak pengetahuan yang dimilki (Agrina, 2011). Semakin tinggi tingkat pendidikan seseorang maka semakin besar kemampuan dalam hal menyerap, menerima informasi, dan pemahaman yang lebih baik terhadap suatu informasi sehingga dapat melakukan tindakan yang tepat dalam mengelola penyakitnya. Serta akan cenderung mematuhi intruksi petugas kesehatan dalam melakukan pengobatan yang meliputi nutrisi medis, olahraga secara teratur, mengkonsumsi obat sesuai resep, serta pemantauan kadar glukosa darah. Tetapi hal ini tidak dapat dilihat dari satu faktor saja, banyak orang yang dengan tingkat pendidikan yang tinggi dan faktor ekonomi yang tinggi pula tetapi tidak bisa menjaga pola makan, yang cenderung lebih suka makanan yang siap saji, yang kaya akan kandungan lemak, gula, dan lain-lain. Faktor yang mempengaruhi lebih banyak pasien dengan tingkat pendidikan yang tinggi dan ekonomi yang tinggi pula tetapi tidak bisa menjaga pola makan yang baik adalah salah satunya dari faktor lingkungan dan aktifitas. Aktifitas yang begitu padat terkadang membuat pasien lupa dalam menjaga kesehatan tubuhnya, sehingga cenderung makan makanan yang instan dan tidak teratur. Selain itu faktor stress kronis yang cenderung membuat seseorang mencari makanan yang manis-manis dan berlemak tinggi untuk meningkatkan kadar serotonin otak. Serotonin ini memiliki efek penenang sementara untuk meredakan stress, tetapi kandungan gula dan lemak yang berbahaya dan 
beresiko terkena diabetes mellitus. Serta faktor lingkungan yang dipengaruhi oleh budaya dilihat dari segi makanannya. Dimana kebanyakan masyarakat Indonesia cenderung meniru budaya dari luar seperti makanan instan (makanan siap saji). Dimana makanan siap saji dapat mempengaruhi pola makan masyarakat Indonesia yang banyak mengandung kalori, kadar lemak, glukosa dan sodium (NA) yang tinggi tetapi rendah serat, vitamin A, kalsium dan folat, sehingga makanan siap saji tersebut dapat berbahaya yang beresiko terkena diabetes mellitus karena mengandung kalori, kadar lemak, glukosa dan sodium (NA) yang tinggi tersebut. Sehingga hal ini mungkin membuat banyak pasien yang menderita diabetes mellitus dengan tingkat pendidikan yantg lebih tinggi.

Tabel 4. Distribusi Pasien Diabetes mellitus Berdasarkan Pekerjaan

\begin{tabular}{ccc}
\hline Pekerjaan & Frekuensi (f)) & Persentase (\%) \\
\hline IRT & 32 & 53,3 \\
Swasta & 1 & 1,7 \\
Wiraswasta & 9 & 15,0 \\
PNS & 15 & 25,0 \\
Pelajar & 3 & 5,0 \\
\hline Total & 60 & 100 \\
\hline
\end{tabular}

Penelitian ini pekerjaan responden cukup beragam yaitu ibu rumah tangga, swasta, wiraswasta, PNS dan pelajar. Sebagian besar responden adalah ibu rumah tangga yaitu 32 pasien (53,3\%). Sedangkan pekerjaan swasta hanya 1 pasien $(1,7 \%)$, pekerjaan wiraswasta sebanyak 9 pasien (15\%), PNS sebanyak 15 pasien $(25,0 \%)$, dan pelajar sebanyak 3 pasien $(5,0 \%)$. Identifikasi pekerjaan ini bertujuan untuk melihat tingkat aktifitas fisik. Karena sebagian besar responden adalah ibu rumah tangga, dengan aktifitas sehari-hari yang cukup aktif seperti membersihkan rumah, memasak, dll. Diasumsikan ibu rumah tangga memiliki aktifitas fisik dan pola gerak badan yang aktif merupakan salah satu faktor yang dapat mengendalikan kadar glukosa darah (Anggun, 2014). Kurangnya aktifitas fisik menjadi faktor resiko terjadinya resistensi insulin. Faktor lain yang mempengaruhi adalah usia. Dimana usia subjek cenderung lebih tua yaitu 36-60 tahun. Sehingga tidak dapat dipastikan bahwa subjek memiliki aktifitas yang aktif. Terlihat dari umur subjek yang tua, dimana Penuaan mempengaruhi banyak hormon yang mengatur metabolisme, reproduksi, dan fungsi tubuh lain yang menyebabkan pasien mudah lelah, pusing, dan lain-lain. Penuaan mempengaruhi sensitivitas sel beta pankreas terhadap glukosa dan menunda pengambilan glukosa oleh insulin, sehingga tidak dapat banyak melakukan aktifitas.

\section{Analisa Tingkat Kepatuhan Konsumsi Obat Pada Pasien Diabetes Mellitus}

Pemberian kuesioner kepatuhan ini bertujuan untuk mengetahui tingkat kepatuhan minum obat diabetes mellitus dengan menggunakan data \% kepatuhan pasien. Penilaian terhadap \% kepatuhan pasien dinilai dengan menggunakan metode MMAS-8 (Morisky Medication Adherence Scale), metode ini dilakukan dengan memberikan delapan pertanyaan dengan aspek yang terdiri dari kelupaan dalam mengonsumsi obat, kesengajaan berhenti mengonsumsi obat tanpa diketahui oleh tim medis, serta kemampuan mengendalikan diri untuk tetap mengonsumsi obat. 
Tabel 5. Kepatuhan Konsumsi Obat pada Subjek Penelitian

\begin{tabular}{ccc}
\hline Kepatuhan & Frekuensi (f)) & Persentase (\%) \\
\hline Patuh & 44 & 73,3 \\
Tidak Patuh & 16 & 26,7 \\
\hline Total & 60 & 100 \\
\hline
\end{tabular}

Penilaian kepatuhan berdasarkan karakteristik pasien yang dilakukan dengan cara pengelompokkan subjek berdasarkan karakteristik jenis kelamin, usia, pendidikan,dan pekerjaan. Hasil penelitian ini menunjukkan bahwa hasil dari kelompok jenis kelamin yaitu rata-rata pasien adalah perempuan. Hasil dari kelompok usia yaitu rata-rata pada usia tua. Hasil dari kelompok pendidikan menunjukkan hasil bahwa subjek berada pada tingkat pendidikan yang tinggi yaitu SMA, dan hasil dari kelompok pekerjaan menunjukkan bahwa rata-rata subjek adalah seorang ibu rumah tangga.

Hasil penelitian tabel 5.6 menunjukkan bahwa tingkat kepatuhan pasien dalam mengkonsumsi obat diabetes mellitus sangat tinggi, dilihat dari hasil tabel dimana pasien yang patuh sebanyak 44 pasien dengan persentase $73,3 \%$, sedangkan pasien yang tidak patuh hanya 16 pasien dengan persentase sebesar 26,7\%. Dari beberapa aspek dalam metode ini terlihat bahwa kemauan yang sangat tinggi pasien untuk sembuh dari penyakit yang diderita sehingga pasien berusaha untuk selalu patuh terhadap intruksi yang diberikan oleh tenaga kesehatan mengenai terapi pengobatan yang diberikan. Jika dilihat dari segi umur hasil penelitian ini seharusnya banyak pasien yang tidak patuh. Hal ini karena subjek penelitian rata-rata berusia tua. Sehingga jika dinilai dari aspek kelupaan, dimana semakin tua, daya mengingat seseorang akan semakin menurun. Tetapi hasil penelitian ini menunjukkan bahwa semakin tua, pasien semakin patuh dalam mengkonsumsi terapi obat. Hal ini kemungkinan dikarenakan lamanya menderita penyakit diabetes mellitus. Semakin lama pasien menderita diabetes mellitus, maka semakin besar kemungkinan untuk menjadi patuh terhadap pengobatan. Selain itu semakin meningkatnya umur akan mempengaruhi motivasi untuk hidup sehat, sehingga tingkat kepatuhan semakin tinggi atau pasien akan semakin patuh. Hubungan usia dengan tingkat kepatuhan pasien yaitu berhubungan dengan daya ingat pasien. Dimana semakin tua, maka daya ingat akan semakin menurun, sehingga meyebabkan tingkat kepatuhan pasien rendah. Tetapi hasil dari penelitian ini menunjukkan hasil sebaliknya. Hal ini dapat diatasi dengan dengan melibatkan keluarga pasien dengan memberikan informasi mengenai kepatuhan pasien dan turut dalam berpatisipasi membantu pasien dalam meningkatkan kepatuhan pengobatannya.

Lamanya menderita penyakit diabetes mellitus juga berpengaruh terhadap kepatuhan pasien. Dimana semakin lama pasien menderita diabetes mellitus, maka semakin besar kemungkinan untuk patuh terhadap pengobatan. Dimana pasien yang patuh dalam penelitian ini rata-rata sudah menderita diabetes mellitus $>5$ tahun, sehingga banyak pengalaman yang diperoleh mengenai penatalaksaan pengobatan diabetes mellitus. Faktor pengalaman berpengaruh terhadap pengetahuan pasien, dimana pasien yang telah lama menderita diabetes mellitus telah memiliki banyak pengalaman terkain penatalaksanaan diabetes mellitus termasuk dalam hal pengaturan makan. Sehingga dapat membuat hidup pasien penjadi lebih baik.

Tingkat pendidikan dalam penelitian ini tidak begitu berpengaruh terhadap tingkat kepatuhan. Dimana semakin tingginya tingkat pendidikan maka diharapkan akan semakin luas pula pengetahuan responden serta semakin mudah dan cepat pula untuk menerima 
berbagai informasi dari berbagai media khususnya tentang gizi dan kaitannya dengan kesehatan. Subjek pada penelitian ini menunjukkan bahwa walaupun pasien memiliki pendidikan yang tinggi, sebagian tidak memahami kondisi penyakitnya sehingga menyebabkan pasien tidak patuh. Disisi lain, subjek dengan tingkat pendidikan yang lebih rendah menyatakan bahwa memeiliki kepercayaan yang lebih terhadap saran dokter sehingga menyebabkan mereka menjadi lebih patuh.Dengan demikian, tingkat pendidikan pada penelitian ini kurang berpengaruh terhadap tingkat kepatuhan. Umumnya pasien dengan tingkat pendidikan yang lebih tinggi memiliki tingkat pengetahuan yang lebih tentang penyakit dan pengobatannya sehingga dapat lebih patuh. Berdasarkan hasil penelitian ini menunjukkan bahwa tingkat pendidikan mungkin bukan prediktor yang baik untuk menentukan tingkat kepatuhan pasien.

\section{KESIMPULAN}

1. Karakteristik pasien diabetes mellitus di instalasi rawat jalan RSUD A.W.Sjahranie adalah $91,7 \%$ pada usia $36-60$ tahun, $66,7 \%$ perempuan, $35,0 \%$ pendidikan terakhir SMA, 53,3\% sebagai ibu rumah tangga, dan 46,7\% menggunakan jaminan kesehatan jamkesda.

2. Tingkat kepatuhan pasien diabetes mellitus sebesar yaitu $73,3 \%$

\section{DAFTAR PUSTAKA}

1. Alfredo Dias Oliveira-Filho, Jose Augusto Barreto Filho, Sabrina Joany felizardo Neves, Divald Pereira de Lyra Junior. 2012. Association Between the 8-item Morisky Modication adherence Scale (MMAS-8) and blood Pressure Control.

2. American Diabetes Association. 2014. Definition and Clasification Of Diabetes Mellitus. Diabetes Care.

3. BPOM. 2010. Badan Pengawas Obat dan Makanan Republik Indonesia. Vol. XI No. 5

4. Brashers, Valentina L. 2007. Aplikasi Klinis Patofisiologis : Pemeriksaan dan Manajemen Edisi Kedua. EGC: Jakarta.

5. Corwin, Elizabetz J. 2009. Patofisiologi. EGC: Jakarta

6. Dipiro, J.T., et.Al. 2008. Pharmacotherapy: A

7. Pathophysiologic Approach, Seventh Edition. Mc-Graw Hill.

8. Tan Hoan Tjay dan Kirana Raharja. 2007. Obat-obat Penting Khasiat, Penggunaan dan Efek-efek Sampingnya Edisi Ke Enam. PT. Elex Media Komputindo. Jakarta.

9. Melanie J. Rantucci. 2009. Komunikasi Apoteker-Pasien Panduan Konseling Pasien. EGC: Jakarta.

10. Michael J. Gobney. 2008. Gizi Kesehatan Masyarakat. EGC: Jakarta

11. Ninuk Dian Kuniawati, S. Kep. NS dan Dr. Nursalam, M.Nurs.(Hons). 2007. Asuhan Keperawatan pada Pasien Terinfeksi HIV/AIDS. Salemba Medika: Jakarta.

12. Nurina Dewi Pratita. 2012. Hubungan Dukungan Pasangan dan Health Locus Of Control dengan Kepatuhan Dalam Menjalani Proses Pengobatan Pada Penderita Diabetes Mellitus Tipe 2. Jurnal Ilmiah Mahasiswi Universitas Surabaya Vol. 1 No.1

13. Siregar, Charles J. P. 2005. Farmasi Klinik: Teori dan Penerapan. EGC: Jakarta

14. Thomas, Timmreck. 2004. Epidemiologi. EGC: Jakarta

15. Umar, Husein. 2002. Metode Riset Bisnis. Gramedia Pustaka Utama: Jakarta 